International Journal of Business Management and Economic Review

Vol. 4, No. 04; 2021

ISSN: 2581-4664

\title{
THE EFFECT OF MOTIVATION AND LEADERSHIP ON WORK PERFORMANCE AND ITS IMPACT ON ORGANIZATIONAL PERFORMANCEOF ENVIRONMENT DEPARTMENT OF PIDIE JAYA
}

\author{
*SyukriItam, Mukhlis and Said Musnadi \\ Management Department, Universitas Syiah Kuala, Indonesia \\ http://doi.org/10.35409/IJBMER.2021.3279
}

\begin{abstract}
This study aims to examine the influence of motivation and leadership on work performance and the impact on organizational performance of the Environment Department of Pidie Jaya District (DLH Pidie Jaya), Indonesia. The population in this study was all employees, both civil servants and contract employees at DLH Pidie Jaya, Indonesia, totaling 68 people. The research sample took the whole population (census). Data were collected using a questionnaire and measured using a Likert scale. The research model was analyzed using the Partial Least Square (PLS).The result of the descriptive hypothesis testing indicates that work motivation, leadership, work performance, and organizational performance of the DLH Pidie Jaya have obtained good performance. The result of direct hypothesis testing shows that work motivation affects work performance, leadership affects work performance, work motivation affects organizational performance, leadership does not affect organizational performance, and work performance affects organizational performance. The result of indirect hypothesis testing shows that work performance mediates partially the effect of work motivation on organizational performance, and work performance fully mediates the effect of leadership on organizational performance. The originality of this research lies in the organizational performance improvement model that has been tested and can be applied at DLH Pidie Jaya.Work motivation can affect organizational performance both directly and through work performance, whereas leadership cannot directly affect organizational performance, but initially leadership must be able to improve work performance and only then will have an impact on organizational performance. For further research, the researcher recommends conducting further testing to be able to improve organizational performance using job satisfaction, expertise, work relations, organizational justice, and work environment variables.
\end{abstract}

Keyword: Work Motivation, Leadership, Work Performance, Organizational Performance.

\section{INTRODUCTION}

Organizational performance as one of the parameters in measuring the achievement of organizational goals is an important thing that must be achieved by every agency. Because performance is a reflection of the agency's ability to manage and allocate its resources. Human resources (HR) are required to provide a competitive advantage to support the sustainability of organizational performance optimally. As one of the District Government Institutions (SKPD) in 


\section{International Journal of Business Management and Economic Review}

Vol. 4, No. 04; 2021

ISSN: 2581-4664

the Pidie Jaya, the Environment Department of Pidie Jaya (DLH Pidie Jaya) in carrying out government duties in the environmental sector, is required to be able to optimize its human resources. Human resource management cannot be separated from employee factors who are expected to perform as well as possible to achieve agency goals. Employees are one of the main resource components and are the main assets that have a strategic role in the organization. They act as managers or executors starting from planning, implementing, controlling, and monitoring all activities of an organization in achieving agency performance following the vision, mission, and objectives of the agency itself.

To support the vision and mission of the Pidie Jaya district, namely "Meuato Ibadat, Meuato Bak Hareukat, Gleeh dan Sehat, Donya Akhirat Beu Sejahtra", DLH Pidie Jaya has carried out various activities following its main duties which involve various elements of the institution, namely Regional Leaders Conference (Muspida), Non-Government Organizations (NGO) and the community. One of the activities routinely carried out is the "Pijay Gleeh" activity. However, overall the organizational performance of DLH Pidie Jaya still needs to be greatly improved so that its vision, mission, and objectives as a public organization can be achieved. The role of DLH Pidie Jaya in creating a conducive environment is very important. Cleanliness and urban planning have always been the spotlight of various elements on the performance of DLH Pidie Jaya because they are still far from appropriate.

Although the leader of DLH Pidie Jaya has implemented the "Pijay Gleh" program which involves various elements of society in creating cleanliness, in various corners of the city there are still piles of garbage scattered about, giving off an unpleasant aroma. The beauty of the environment is also not comprehensive in the Pidie Jaya district, there are still many forests, plantations, and not maintained. This proves that DLH Jaya's performance has not been maximal in carrying out its role as a public sector organization. Besides, the problem of controlling the quantity and quality of the population's environment and the lack of maximum participation and role of the community in environmental management shows that the overall performance of DLH Pidie Jaya is still low and desperately needs a strategic effort to fix it.

Besides, adhering to the results of the 2019 DLH Pidie Jaya performance evaluation shows that many achievement figures are still below the target/expectation. Likewise, the total absorption of DLH Pidie Jaya's budget has not reached $100 \%$. This figure also shows that the performance of the organization as a public organization is still not optimal. Of course DLH Jaya still really needs smart work by mobilizing all available resources to achieve organizational goals, both human resources, technology, supporting facilities, and a conducive work environment that can support the performance of employees in achieving more organizational performance outputs.

Another phenomenon that occurs in the field shows that there is a mismatch between expectations and reality. This is evidenced by the fact that there are still employees who are often absent and absent from work and often chat during working hours. The phenomenon of work performance appraisal that occurs is often that the work performance appraisal received by employees contains a lot of subjective elements and it can be said that it no longer provides an overall picture of employee performance, because often superiors only provide an assessment of the employee's work the last two months before the work performance appraisal is carried out and no longer based on the achievements during the year as specified earlier. This proves that the work performance of DLH Pidie Jaya employees requires full attention by the SKPD leadership 


\section{International Journal of Business Management and Economic Review}

Vol. 4, No. 04; 2021

ISSN: 2581-4664

because if this cannot be resolved it will have an impact on the entire system being run so that the goal as a public organization is to provide the best possible service to the community cannot be achieved.

Factors that affect work performance and have an impact on organizational performance are work motivation and leadership factors. Various motivational factors as described in the hierarchy(Maslow, 1943)This has been implemented by the Pidie Jaya District Government to encourage employee motivation, including within the DLH Pidie Jaya, such as meeting basic needs (salary, allowances, housing, security in the work environment), career certainty, democratic and open leadership, and various instruments. other motivation. All of these are expected to be a big enough work motivation factor in enhancing the morale of an employee.

However, in line with the conditions in the DLH Pidie Jaya where the current salary level is no longer in line with current economic conditions, this is felt by most employees, both civil servants, and contracts. Besides, career development is quite complicated, so that many employees for promotion at this time have to take part in various activities related to improving employee skills, career opportunities, work opportunities and experience, where this condition is not fully achievable by every employee and has an impact on motivation. employee work. Meanwhile, leadership is a complex phenomenon so that it is very difficult to make a comprehensive formula about the meaning of leadership. However, leadership in general can be interpreted as the ability of an individual or organization to guide people, teams (groups), or organizations to achieve predetermined goals and objectives. This guiding ability from the perspective of the behavioral theory of leadership is obtained through a learning process that will form a behavioral of leadership that will stimulate a person.

\section{LITERATURE REVIEW}

An organization is said to be high performance if the organization is able to produce a planned performance on quality improvement by utilizing great human resources. The organizational performance consists of the results obtained compared to work targets(MBN, 2019).According to(Sinaga \& Sinambela, 2013)organizational performance is defined as overall effectiveness to meet the defined needs of each group concerned through systematic efforts and continuously improve the organization's ability to achieve its needs effectively. Organizational performance can also be said that an organization that is able to achieve targets effectively and efficiently by utilizing its resources and organizational success illustrates a high return on equity due to the formation of good organizational management. According to the contingency theory(Boyatzis, 1982)to achieve organizational targets (best fit), there are three dimensions that will influence it, each individual dimension, job demand, and organizational environment. These three dimensions then differentiate several other variables and indicators including, motivation, leadership, organizational climate, values, culture, functions and roles and so on. Another opinion expressed by(Pasolong, 2015)organizational performance is the overall effectiveness of the organization for the interests determined by each organization related to systemic activities in increasing organizational expertise continuously to achieve effective and efficient expectations.

The latest development of the concept of performance is popular with the term performance excellence which has a controlled approach to managing organizational performance whose results convey high value for utilization that contributes to the achievement of organizational success, improvement of overall organizational effectiveness and capacity and 


\section{International Journal of Business Management and Economic Review}

Vol. 4, No. 04; 2021

ISSN: 2581-4664

the concept of educating organizations and members. The concept of performance now provides a design and assessment medium in analyzing the organization's capabilities and opportunities to improve so that it becomes a work program guideline. Organizational performance can be influenced by several factors as disclosed by(Wibowo, 2015), namely personal/individual factors, leadership factors, team factors, and system factors. Besides(Pasolong, 2015)also revealed that the factors that influence organizational performance are the external environment, motivation, and organizational capacity. In addition, organizational performance is also influenced by work performance factors. This is in line with the research results(Herlina, 2017) work performance can make a positive contribution to employee performance. The higher the work performance, the more it will have an impact on organizational performance. Similar results are also evidenced by(Yamanie \& Syaharuddin, 2016)work performance (X1) has a positive effect on performance (Y). Based on the various income and research results, the following hypothesis can be expressed

Ha6 : Work Performance affects the Organizational Performance of the DLH Pidie Jaya.

Employee performance is the achievement of employee performance in one year and provides an overview of organizational performance.(Mangkunegara, 2013)disclosed work performance as a result of work in terms of quantity and quality achieved by an employee in carrying out his duties following the responsibilities assigned to him. Many factors affect employee performance. According to(Suprihatiningrum \& Bodroastuti, 2012)factors that affect work performance, namely: work motivation, job satisfaction, job stress levels, physical conditions of work, compensation systems, leadership and job design. While(Soetrisno, 2016)said that in general, people believe that individual work performance is a combined function of three factors, namely ability, temperament, interest, clarity, acceptance and level of work motivation. Based on the various inputs and explanations, the following hypotheses can be expressed

Ha2 :Work Motivation affects the Work Achievement of DLH Pidie Jaya Employees.

Ha3: Leadership affects the work performance of DLH Pidie Jaya Employees.

Employee work motivation is also one of the factors that can affect organizational performance. (Bangun, 2012)defined motivation as a condition that encourages or causes someone to do an action/activity that takes place consciously. Motivation is an important determinant of individual achievement in addition to past skills, abilities and experiences(Fachreza, Musnadi, \& Shabri, 2018). Every human being works aims to be able to meet his life needs, even though the motive for work and the level of the needs of each individual is not the same. High work motivation will have a positive impact on the performance of employees and employees who have high performance will have a positive impact on organizational performance. achieve the goals of the organization. As revealed by(Mangkunegara \& Octorend, 2015)motivation is a condition that moves employees to be able to achieve the goals of their motives. High motivation can make the factors that direct and encourage a person's behavior or desire to do something that is expressed in the form of hard effort. Based on the various income and research results, the following hypotheses can be expressed

Ha4 : Work Motivation affects the Organizational Performance of the DLH Pidie Jaya. 


\section{International Journal of Business Management and Economic Review}

Vol. 4, No. 04; 2021

ISSN: 2581-4664

Another factor that affects organizational performance is the leadership factor. In an organization or company, leadership is an important factor in achieving organizational performance following its objectives. (Robbins \& Judge, 2014)stated that motivation is a process that explains the intensity, direction and persistence of an individual to achieve his goals. According to(Northouse, 2013)Leadership style is a set of characteristics used by leaders to influence subordinates in achieving organizational goals or objectives. The good and bad performance of a leader will have a direct impact on organizational performance. Based on the various income and research results, the following hypotheses can be expressed

Ha5 : Leadership affects the Organizational Performance of the DLH Pidie Jaya.

As for the research on organizational performance measurement using indicators as disclosed by(Pasolong, 2015)namely productivity, service quality, responsiveness, responsibility, and accountability. The measurement of work excitation uses the indicators mandated in Government Regulation No. 46/2011, namely: quality of work, quantity of work, timeframe, cost-effectiveness, service orientation, integrity, commitment, discipline, cooperation, and leadership. The measurement of work motivation uses the indicators disclosed by(Robbins \& Judge, 2014)these include, among others: (1) The quality of the work produced increases, (2) Tasks according to ability, (3) High work initiatives, (4) Work relations and (5) Sacrifice. While the measurement of leadership uses the indicators disclosed by(Siagian, 2014)namely telling, selling, participating, and delegating.

\section{Research Model and Hypotheses}

The research model and complete hypotheses that explain the relationship between variables can be described as follows :

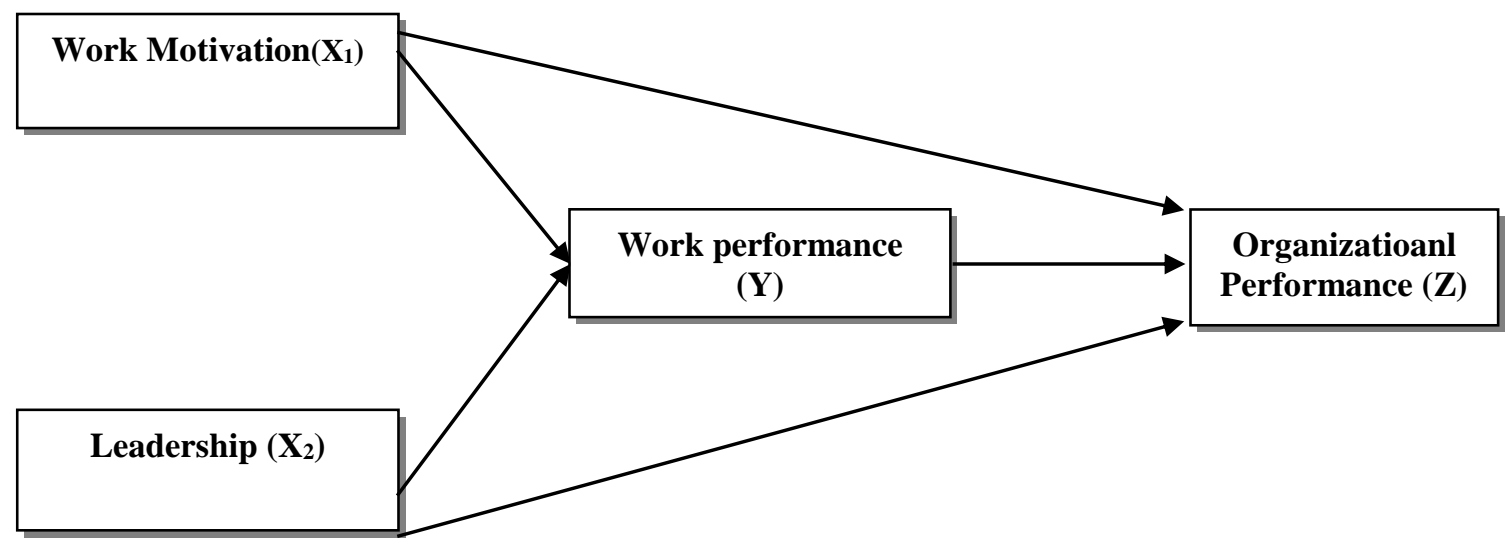

Figure 1. Research Model

Ha1: Work Motivation, Leadership, Work Performance, and Organizational Performance of the DLH Pidie Jayaare good.

Ha2 : Work Motivation affects the work performance of DLH Pidie Jaya Employees.

Ha3: Leadership affects the work performance of DLH Pidie Jaya Employees.

Ha4: Work Motivation affects the Organizational Performance of the DLH Pidie Jaya. 
Ha5 : Leadership affects the Organizational Performance of the DLH Pidie Jaya.

Ha6 : Work Performance affects the Organizational Performance of the DLH Pidie Jaya.

Ha7: Work Motivation affects Organizational Performance through Employee Work Performance of the DLH Pidie Jaya.

Ha8: Leadership affects Organizational Performance through the Employee Work Performance of the DLH Pidie Jaya.

\section{RESEARCH METHOD}

This research was conducted at the Environment Department of Pidie Jaya (DLH Pidie Jaya), Indonesia. The research object waswork motivation, leadership, work performance, and organizational performance of the DLH Pidie Jaya. In this study, the number of sample equated with the number of population (census method), totaling 68 employees. Data were collected using a questionnaire method, where the list of questions asked provided answers using a Likert scale.

For testing direct hypotheses and indirect hypotheses in this study was used the SEM Variance Based statistical tool or also known as Partial Least Squares (PLS), is one of the multivariate data analysis techniques(F. Hair Jr, Sarstedt, Hopkins, \& G. Kuppelwieser, 2014), and the software used was SmartPLS. Then the structural equation is as follows:

Information:

$$
\begin{aligned}
& \eta_{1}=\gamma_{1} \xi_{1}+\gamma_{2} \xi_{2}+\varsigma_{1} \\
& \eta_{2}=\gamma_{3} \xi_{1}+\gamma_{4} \xi_{2}+\beta_{1} \eta_{1}+\varsigma_{2}
\end{aligned}
$$

$\xi_{1}=$ Motivation

$\xi_{2}=$ Leadership

$\eta_{1}=$ Work Performance

$\eta_{2}=$ Organizational Performance

$\gamma=$ The coefficient of influence of exogenous variables on endogenous variables

$\beta=$ The coefficient of the influence of endogenous variables on endogenous variables

$\varsigma=$ estimate of error

\section{RESULT AND DISCUSSION}

\section{Descriptive Hypothesis Testing For H1}

Based on the results of the analysis of respondents' perceptions of the research variables, it was found that the average value of organizational performance was 3.84 , the mean value of work performance was 3.79 , the mean value of work motivation was 3.84 , and the mean value of leadership was 3,75. Overall, it was known that the mean value of respondents' perceptions of the research variables is 3.81> 3.41. Descriptive hypothesis testing was carried out using a onesample test with a cut off value of 3.41 with the following results:

\section{Table 1. Testing One-Sample Test}

\begin{tabular}{|l|l|l|l|l|l|l|}
\hline \multirow{2}{*}{} & \multicolumn{3}{|l|}{ Test Value $=3.41$} \\
\cline { 2 - 6 } & $\mathrm{t}$ & df & $\begin{array}{l}\text { Sig. (2- } \\
\text { tailed })\end{array}$ & $\begin{array}{l}\text { Mean } \\
\text { Difference }\end{array}$ & $\begin{array}{l}\text { 95\% Confidence Interval of the } \\
\text { Difference }\end{array}$ \\
\cline { 5 - 6 } & & & Lower & Upper \\
\hline
\end{tabular}


International Journal of Business Management and Economic Review

Vol. 4, No. 04; 2021

ISSN: 2581-4664

\begin{tabular}{|l|l|l|l|l|l|l|}
\hline \hline Work Motivation & 3.525 & 67 & .001 & .42529 & .1845 & .6661 \\
\hline Leadership & 3.391 & 67 & .001 & .34368 & .1414 & .5460 \\
\hline Work Performance & 3.845 & 67 & .000 & .38118 & .1833 & .5790 \\
\hline $\begin{array}{l}\text { Organizational } \\
\text { Performance }\end{array}$ & 3.716 & 66 & .000 & .41388 & .1915 & .6362 \\
\hline
\end{tabular}

Source: Processed data (2021)

Based on table 1 above, it can be seen that the test results of one sample test with a test value $=3.41$. Significance Value / Sig. $(2$ tailed) the work motivation variable is 0.001 , the leadership variable is 0.001 , the work performance variable is 0.000 , and the organizational performance variable is 0.000. All Significance Values / Sig. (2 tailed) is below 0.05. With this, it can be concluded that for testing the descriptive hypothesis (H1) is good where Ha1 is accepted and Hol is rejected. This shows that the variables of work motivation, leadership, work performance, and organizational performance are good.

\section{Partial Least Squares Analysis}

The structural model analysis that explains the effect test between variables is presented in the following path diagram:

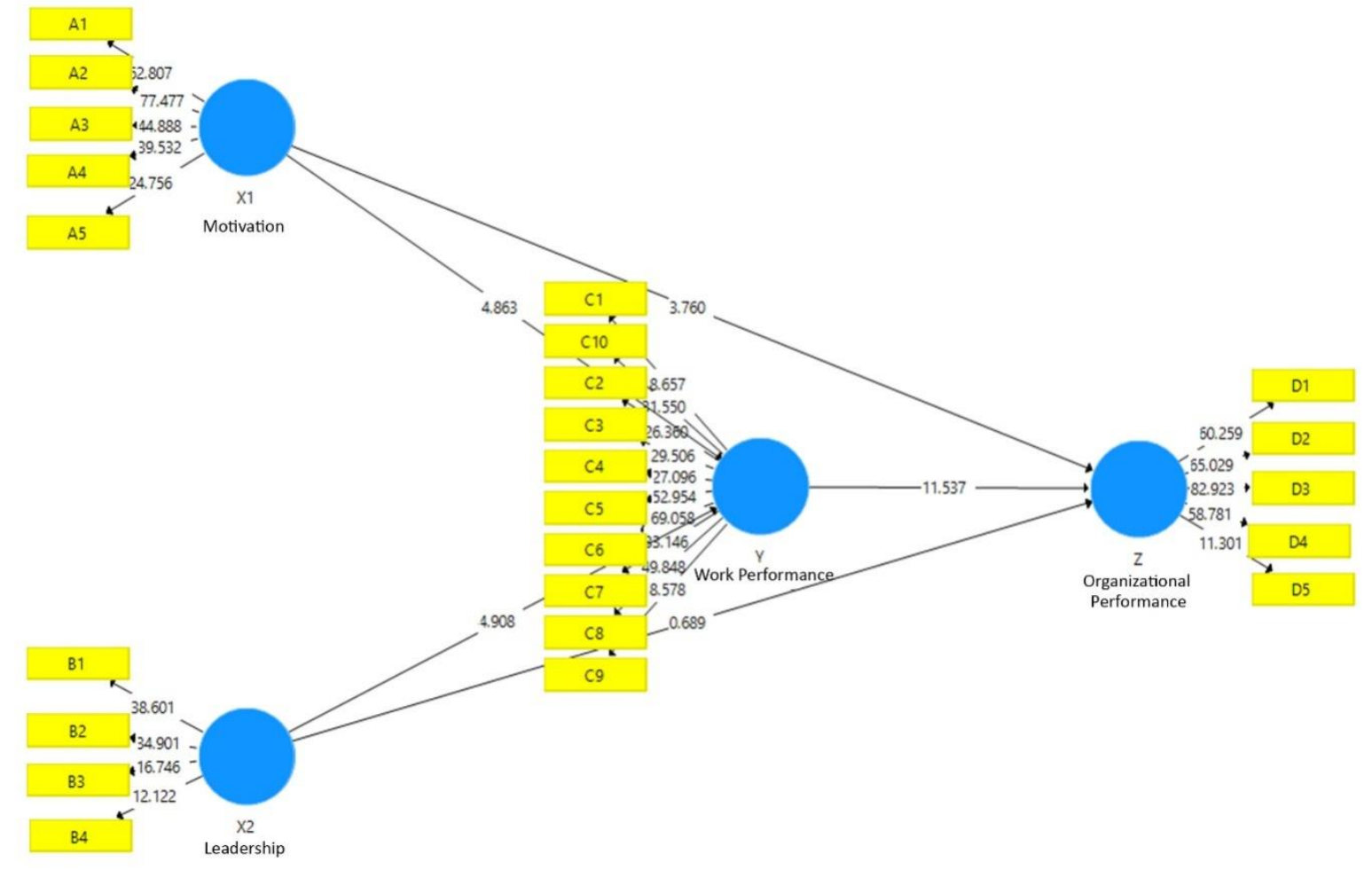

Figure 2. PLS Test Result

Figure 2 above shows the influence between variables, namely the motivation, leadership, work performance and organizational performance. 


\section{Direct Path (H2, H3, H4, H5, and H6)}

Based on the PLS test as shown in Figure 2 above, the results obtained are as follows.

Table 2. Direct Hypothesis Testing Results

\begin{tabular}{|l|l|l|l|l|l|}
\hline Inter-Variable & $\begin{array}{l}\text { Original } \\
\text { Sample } \\
(\mathbf{O})\end{array}$ & $\begin{array}{l}\text { Sample } \\
\text { Mean } \\
(\mathbf{M})\end{array}$ & $\begin{array}{l}\text { Standard } \\
\text { Deviation }\end{array}$ & $\begin{array}{l}\text { T } \\
\text { Statistics }\end{array}$ & P Values \\
\hline $\begin{array}{l}\text { X1_Work Motivation - } \\
\text { >Y_Work Motivation }\end{array}$ & 0.429 & 0.437 & 0.088 & 4.863 & 0.000 \\
\hline $\begin{array}{l}\text { X1__Work Motivation - } \\
\text { >Z_Organizational Performance }\end{array}$ & 0.260 & 0.253 & 0.069 & 3.760 & 0.000 \\
\hline $\begin{array}{l}\text { X__Leadership->Y_ Work } \\
\text { Motivation }\end{array}$ & 0.486 & 0.472 & 0.099 & 4.908 & 0.000 \\
\hline $\begin{array}{l}\text { X2_ Leadership->Z_ } \\
\text { Organizational Performance }\end{array}$ & -0.046 & -0.038 & 0.067 & 0.689 & 0.491 \\
\hline $\begin{array}{l}\text { Y_ Work Motivation -> Z_ } \\
\text { Organizational Performance }\end{array}$ & 0.776 & 0.776 & 0.067 & 11.537 & 0.000 \\
\hline
\end{tabular}

Source: Primary data, 2020 (processed)

By looking at the test results in table 2 above, the results of direct hypothesis testing are explained as follows:

\section{$\underline{\mathrm{H} 2}$ :Testing the Effect of Work Motivation on Work Performance}

Testing hypothesis 2, namely the effect of work motivation on work performance of the employees of DLH Pidie Jaya, obtained a path coefficient of 0.429 . The statistical $\mathrm{T}$ value is $4.863>1.96$ and the P-value is $0.000<0.05$. This value shows that work motivation significantly affects the work performance of the DLH Pidie Jayaemployees. The amount of direct influence of work motivation on employee performance is 0.429 or $42.9 \%$. These results indicate that the $\mathrm{Ha} 2$ is accepted and $\mathrm{Ho} 2$ is rejected. This follows the results of research conducted by(Rosmanidar, Hafasnuddin, \& Nurdin, 2020), (Mangngi, Fanggidae, \& Nursian, 2018), and(Mohamud, Ibrahim, \& Hussein, 2017).They found that there was a significant influence between employee motivation and employee performance.

This proves that the higher the work motivation of an employee, the higher the work performance that is created. To achieve the goals of an organization, high employee motivation is needed. For this reason, the DLH Pidie Jaya must continue to strive to create work motivation for its employees towards a better direction in carrying out their daily duties as state servants. One of the efforts that must be made by management or structural officials within the DLH Pidie Jayato increase employee motivation is by assessing the level of ability of employees and efforts to improve it by providing training, training and always improving a more harmonious work relationship and high togetherness in the work unit. Another thing that must be done by the DLH Pidie Jayais to be fair in matters such as promotions, bonuses and so on. Following its definition, motivation is a force that encourages a person's spirit that comes both from within and from his environment. 
International Journal of Business Management and Economic Review

Vol. 4, No. 04; 2021

ISSN: 2581-4664

H3 :Testing the Effect of Leadership on Work Performance

Testing hypothesis 3 , namely the effect of leadership on the work performance of the employees of the DLH Pidie Jaya, the path coefficient value is 0.486 . The statistical T value is 4.908> 1.96 and the $\mathrm{P}$-value is $0.000<0.05$. This value shows that leadership significantly affectsthe work performance of the employees of the DLH Pidie Jaya. Based on the value of the original sample, it can be seen that the direct influence of leadership on the work performance of the employees of the DLH Pidie Jaya is $48.6 \%$. These results indicate that the Ha3 accepted and Ho3 rejected. This follows the results of research conducted by(Lai, Tang, Lu, Lee, \& Lin, 2020), (Rosmanidar et al., 2020), (Kundu, Kumar, \& Gahlawat, 2019), (Madi \& Djuharni, 2017)and(Musnadi \& Chan, 2013)which proved that leadership had a significant effect on work performance.

The role of the DLH Pidie Jaya in creating beautiful city planning is inseparable from the work achievements of its employees. Office leaders must be able to accommodate the capabilities of each employee so that the workload assigned is following the capabilities of each employee. The abilities possessed by each employee will be able to achieve good work performance and following expectations. Besides, leaders must also have creative ideas so that problems that occur in the organization can be resolved properly and can realize the goals of the organization.

\section{H4 :Testing the Effect of Work Motivation on Organizational Performance}

Testing Hypothesis 4, the effect of employee work motivation on organizational performance of the DLH Pidie Jaya, obtained a path coefficient value of 0.260 . The statistical T value is $3.760>1.96$ and the $\mathrm{P}$-value is $0.000<0.05$. This value shows that employee work motivation significantly affectsthe organizational performance of the DLH Pidie Jaya. Based on the value of the original sample, it can be seen that the direct influence of employee motivation on the organizational performance of the DLH Pidie Jayais 26.0\%. These results indicate that Ha4 is accepted and Ho4 is rejected. This follows the results of research conducted by(Suwaji, 2019), (Deressa \& Zeru, 2019), (Rismayadi \& Maemunah, 2016), and (Lee \& Raschke, 2016)where they also proved that work motivation had a significant effect on organizational performance.

These results also prove that the better or the higher the motivation of employees, the better the resulting organizational performance. For this reason, every organization needs to take seriously the increasing work motivation of its employees, especially the DLH Pidie Jaya, whose performance benchmarks have a direct impact on society such as urban planning, environmental cleanliness, prevention of pollution and environmental destruction. So to improve employee work motivation continuously, the management of the DLH Pidie Jaya must always pay attention to things in the form of improving the quality of work, assigning tasks according to their abilities and always striving to increase high work initiatives for their employees.

\section{H5 :Testing the Effect of Leadership on Organizational Performance}

Testing hypothesis 5 about the effect of leadership on organizational performance of the DLH Pidie Jayaobtained a path coefficient value of -0.046 . The statistical T value is $0.689<1.96$ and the P-value is 0.491>0.05. This value shows that leadership does not affect the 


\section{International Journal of Business Management and Economic Review}

Vol. 4, No. 04; 2021

ISSN: 2581-4664

organizational performance of the DLH Pidie Jaya. These results indicate that the Ha5 is rejected and Ho5 is accepted. This result follows the results of research conducted by(Noviyanti, Syofyan, \& Evanita, 2019), (Wani, Adam, \& Majid, 2018), and (Rismayadi \& Maemunah, 2016)where the results of their research indicated that leadership did not influence organizational performance.So in this study, leadership is not directly able to influence organizational performance. However, many pieces of literature said leadership can also affect organizational performance through other variables such as work performance or employee performance, and job satisfaction.

H6 :Testing the Effect of Work Performance on Organizational Performance

Testing hypothesis 6 about the effect of employee work performance on the performance of DLH Pidie Jaya obtained a path coefficient value of 0.776 . The statistical $\mathrm{T}$ value is $11.537>$ 1.96 and the $\mathrm{P}$-value is $0.000<0.05$. This value shows that employee work performance significantly affects the organizational performance of the DLH Pidie Jaya. Based on the value of the original sample, it can be seen that the direct influence of employee motivation on the organizational performance of the DLH Pidie Jaya is $77.6 \%$. These results indicate that the Ha6 is accepted and Ho6 is rejected. This result follows the results of research conducted by(Hadian, 2019), (Kenny S, 2019), (Tarmidi \& Arsjah, 2019), (Ritonga, 2018), and (Ilahi, Mukzam, \& Prasetya, 2017)who found that work performance had a significant effect on organizational performance.

These results indicate that the higher the work performance of the DLH Pidie Jaya employees, the better the organizational performance as a public sector organization. For this reason, work performance appraisal is very important in an organization, to evaluate the extent to which employees have carried out their duties properly, where feedback on work implementation allows employees, leaders, and organizations to correct their activities to improve work performance(Ritonga, 2018). Organizations must continue to strive to be able to improve the work performance of their employees. Increasing the ability of employees can be done by providing training, training, or other education related to the workload entrusted to employees.

\section{Indirect Path (H7 and H8)}

Based on the PLS test as shown in Figure 2 above, for indirect hypothesis testing the following results are obtained

Table 3. Results of Indirect Hypothesis Testing

\begin{tabular}{|c|c|c|c|c|c|}
\hline Inter-Variable & $\begin{array}{l}\text { Original } \\
\text { Sample } \\
\text { (O) }\end{array}$ & $\begin{array}{l}\text { Sample } \\
\text { Mean } \\
\text { (M) }\end{array}$ & $\begin{array}{l}\text { Standard } \\
\text { Deviation }\end{array}$ & $\begin{array}{l}\mathbf{T} \\
\text { Statistics }\end{array}$ & P Values \\
\hline $\begin{array}{lr}\text { X1_Work } & \text { Motivation } \\
\text { Y_Work } & \text { Performance-> } \\
\text { Z_Organizational Performance }\end{array}$ & 0.333 & 0.340 & 0.080 & 4.172 & 0.000 \\
\hline $\begin{array}{l}\text { X2_Leadership-> } \quad Y_{-} \text {Work } \\
\text { Performance-> } \\
\text { Z_Organizational Performance }\end{array}$ & 0.377 & 0.364 & 0.075 & 5.025 & 0.000 \\
\hline
\end{tabular}

Source: Processed Data (2021) 


\section{International Journal of Business Management and Economic Review}

Vol. 4, No. 04; 2021

ISSN: 2581-4664

By looking at the test results in table 3 above, the results of direct hypothesis testing can be explained as follows:

$\underline{\mathrm{H} 7}$ :Testing the Effect of Work Motivation on Organizational Performance through Work Performance

Testing hypothesis 7 regarding the effect of work motivation on organizational performance of the DLH Pidie Jaya through work performance obtained a path coefficient value of 0.333 . The statistical $\mathrm{T}$ value is $4.172>1.96$ and the $\mathrm{P}$-value is $0.000<0.05$. Based on the significant calculation for line $C^{\prime}$, the significant value for all paths (A, B, C and $\left.C^{\prime}\right)$ is shown in Figure 3 below

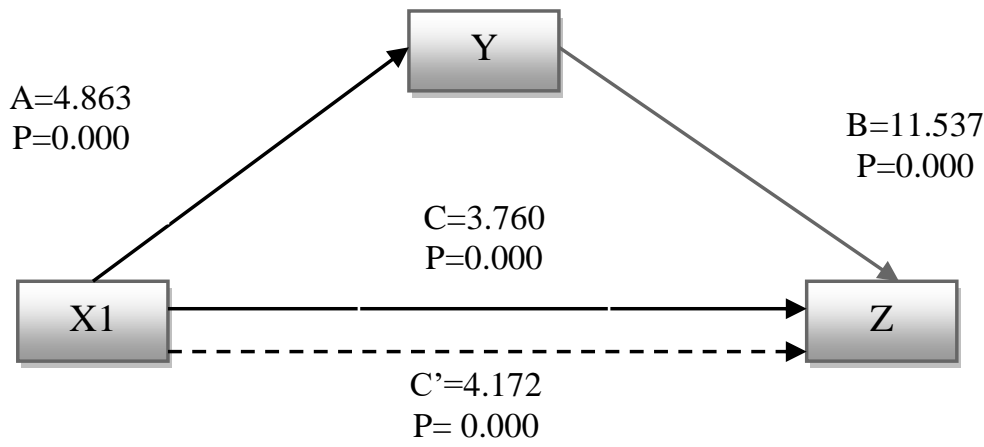

Figure 3. Hypothesis 7Test Result

Figure 3reveals that the coefficient of path A, B, C and $C^{\prime}$ are significant. These results state that work performance partially mediates the effect of work motivation on the organizational performance of the DLH Pidie Jaya, meaning that the results of testing hypothesis 7 show that the $\mathrm{Ha} 7$ is accepted and $\mathrm{Ho} 7$ is rejected. The magnitude of the work performance variable as mediation is $33.3 \%$. These results prove that the higher the level of work motivation possessed by the employees of the DLH Pidie Jaya, the higher the work performance of employees will be created and will indirectly improve organizational performance. This result follows the results of research conducted by(Dewi, Fikri, \& Fitrio, 2019), (Al-Musadieq, Raharjo, \& Fernandes, 2018), and (Fachreza et al., 2018)which proved that employee work performance mediated the effect of work motivation on organizational performance.

$\underline{\mathrm{H} 8}$ :Testing the Effect of Leadership on Organizational Performance through Work Performance

Testing hypothesis 8 regarding the influence of leadership on organizational performance of the DLH Pidie Jayathrough work performance obtained a path coefficient value of 0.377 . The statistical $\mathrm{T}$ value is 5.025> 1.96 and the $\mathrm{P}$-value is $0.000<0.05$. Based on the significant calculation for line $\mathrm{C}^{\prime}$, the significant value for all paths $\left(\mathrm{A}, \mathrm{B}, \mathrm{C}\right.$, and $\left.\mathrm{C}^{\prime}\right)$ are as shown in Figure 4 below 


\section{International Journal of Business Management and Economic Review}

Vol. 4, No. 04; 2021

ISSN: 2581-4664

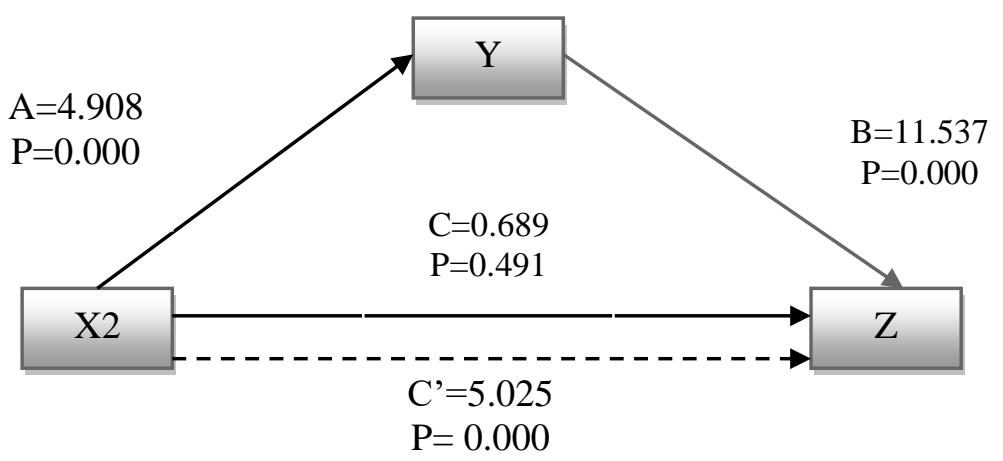

Figure 4. Hypothesis 8Test Result

Figure 4explains that the coefficient of the path of A, B, and C'are significant and the path of $\mathrm{C}$ is not significant. These results state that work performance fully mediates the influence of leadership on the organizational performance of the DLH Pidie Jaya, meaning that the results of testing hypothesis 8 show the Ha8 is accepted and Ho8 is rejected. These results prove that the more the role of a food leader, the better the work performance obtained by employees and will have an impact on the better the organizational performance of the DLH Pidie Jaya. These result follows the results of research conducted by(Hadian, 2019), (Para-González, Jiménez-Jiménez, \& Martínez-Lorente, 2018), (Rathore, Khaliq, \& Aslam, 2017)and(Madi \& Djuharni, 2017)which stated that the influence of leadership on organizational performance can also be mediated by other factors.

\section{CONCLUSION}

From the results of research conducted at the DLH Pidie Jaya, the following conclusions can be drawn:

1. The results of the descriptive hypothesis testing, namely work motivation, leadership, work performance and organizational performance, the DLH Pidie Jaya obtained good results. This can be seen from the overall mean value of respondents' perceptions of the research variables amounted to 3.81> 3.41. By using one sample test with a cut-off value of 3.41 where the results obtained the provability value for all variables is $0.000<0.05$.

2. The results of direct path hypothesis testing show that work motivation significantly affects work performance, leadership significantly affects work performance, work motivation significantly affects organizational performance, leadership does not affect organizational performance, and work performance significantly affects organizational performance.

3. The results of testing the indirect hypothesis (indirect path) show that work performance mediates partially the effect of work motivation on organizational performance, and work performance fully mediates the effect of leadership on organizational performance. 


\section{International Journal of Business Management and Economic Review}

Vol. 4, No. 04; 2021

ISSN: 2581-4664

The research result also provides several Suggestions as follows.

1. To improve the organizational performance of the DLH Pidie Jaya, the factors that must be improved are by increasing the work performance of employees through policy intervention and increasing the ability of employees by providing training, seminars, workshops, education and training, and encouraging each employee to take higher-level studies. Management should also be able to increase responsibility and service quality to result in better organizational performance.

2. Work performance is the most important thing that must be owned by any organization, especially in the DLH Pidie Jaya. To be able to further increase the work prestige possessed by employees, the management of the department must be able to further improve employee work discipline, create good teamwork, foster a high commitment to employees, and create high-quality work.

3. Work motivation is one of the factors that affect the organizational performance of the DLH Pidie Jaya both directly and indirectly through work performance, therefore the leadership and ranks of the DLH Pidie Jayamust also be able to increase the work motivation of its employees. One way to increase employee motivation is through giving attention, inspiration, rewarding opportunities, constructive feedback, information on the latest developments from the organization to employees and helping the team solve the problems at hand so that it can increase work motivation for these employees.

\section{REFERENCES}

Al-Musadieq, M., Raharjo, K., \& Fernandes, A. A. R. (2018). The mediating effect of work motivation on the influence of job design and organizational culture against HR performance. Journal of Management Development, 37(1), 452-469. https://doi.org/https://doi.org/10.1108/JMD-07-2017-0239

Bangun, W. (2012). Manajemen Sumber Daya Manusia. Jakarta: Erlangga.

Boyatzis, R. E. (1982). The Competent Manager: A Model for Effective Performance. New York: Wiley.

Deressa, A. T., \& Zeru, G. (2019). Work motivation and its effects on organizational performance: The case of nurses in Hawassa public and private hospitals: Mixed method study approach. BMC Research Notes, 12(1), 1-6. https://doi.org/https://doi.org/10.1186/s13104-019-4255-7

Dewi, P., Fikri, K., \& Fitrio, T. (2019). The Effect of Work Motivation on Employees' Performance Mediated by Job Performance at Pt. Bank Rakyat Indonesia TBK Rengat Branch Office. International Journal of Scientific Research and Management, 7(9), 13441358.

F. Hair Jr, J., Sarstedt, M., Hopkins, L., \& G. Kuppelwieser, V. (2014). Partial least squares structural equation modeling (PLS-SEM) An emerging tool in business research. European Business Review, 26(2), 106-121.

Fachreza, Musnadi, S., \& Shabri, M. (2018). Pengaruh Motivasi Kerja, Lingkungan Kerja, dan Budaya Organisasi Terhadap Kinerja Karyawan dan Dampaknya Pada Kinerja Bank Aceh 


\section{International Journal of Business Management and Economic Review}

Vol. 4, No. 04; 2021

ISSN: 2581-4664

Syariah Di Kota Banda Aceh. Jurnal Magister Manajemen, 2(1), 115-122.

Hadian, D. (2019). Effect Of Job Satisfaction On Work Discipline Mediated By Continuance Commitment. Jurnal Ekonomi, Bisnis \& Entrepreneurship, 13(1), 17-24. https://doi.org/10.5281/zenodo.3522777

Herlina. (2017). Pengaruh Prestasi Kerja Terhadap Kinerja Karyawan PT. Retail Bandung. Socio Preneur, 1(2), 1-10.

Ilahi, D. K., Mukzam, M. D., \& Prasetya, A. (2017). Pengaruh Kepuasan Kerja terhadap Disiplin Kerja dan Komitmen Organisasional (Studi pada Karyawan PT. PLN (Persero) Distribusi Jawa Timur Area Malang). Jurnal Administrasi Bisnis (JAB), 44(1), 31-39.

Kenny S, V. (2019, April). Employee productivity and organizational performance: A theoretical perspective. Munich Personal RePEc Archive, 1-10. Retrieved from https://mpra.ub.unimuenchen.de/93294/1/MPRA_paper_93294.pdf

Kundu, S. C., Kumar, S., \& Gahlawat, N. (2019). Empowering leadership and job performance: mediating role of psychological empowerment. Management Research Review, 42(5), 605624. https://doi.org/https://doi.org/10.1108/MRR-04-2018-0183

Lai, F.-Y., Tang, H.-C., Lu, S.-C., Lee, Y.-C., \& Lin, C.-C. (2020). Transformational Leadership and Job Performance: The Mediating Role of Work Engagement. Sage Open, 10(1), 1-11. https://doi.org/https://doi.org/10.1177/2158244019899085

Lee, M. T., \& Raschke, R. L. (2016). Understanding employee motivation and organizational performance: Arguments for a set-theoretic approach. Journal of Innovation \& Knowledge, 1(3), 162-169. https://doi.org/10.1016/j.jik.2016.01.004

Madi, Y. A., \& Djuharni, D. (2017). Pengaruh Gaya Kepemimpinan Dan Motivasi Kerja Terhadap Prestasi Kerja Pegawai Pada Kantor Wilayah Direktorat Jenderal Perbendaharaan Di Kota Kupang. Jurnal Administrasi Dan Bisnis, 11(1), 19-26.

Mangkunegara, A. P. (2013). Manajemen Sumber Daya Manusia Perusahaan. Bandung: Remaja Rosdakarya.

Mangkunegara, A. P., \& Octorend, T. R. (2015). Effect of Work Discipline, Work Motivation and Job Satisfaction on Employee Organizational Commitment in the Company (Case Study in PT. Dada Indonesia). Universal Journal of Management, 3(8), 318-328. https://doi.org/10.13189/ujm.2015.030803

Mangngi, R. F., Fanggidae, R. E., \& Nursian, N. P. (2018). Pengaruh Motivasi Terhadap Prestasi Kerja Karyawan Pada PT. Pos Indonesia (Persero) Cabang Kupang. Journal of Magement, 7(2), 207-224.

Maslow, A. H. (1943). A Theory of Human Motivation. Psychological Review, 50, 370-396.

MBN. (2019). Organizational performance - definition and meaning. Retrieved May 11, 2020, from Market Business News website: https://marketbusinessnews.com/financialglossary/organizational-performance-definition-meaning/

Mohamud, S. A., Ibrahim, A. A., \& Hussein, J. M. (2017). The Effect Of Motivation On 


\section{International Journal of Business Management and Economic Review}

Vol. 4, No. 04; 2021

ISSN: 2581-4664

Employee Performance: Case Study In Hormuud Company In Mogadishu Somalia. International Journal of Development Research, 7(11), 17001-17008.

Musnadi, S., \& Chan, S. (2013). Pengaruh Gaya Kepemimpinan, Budaya Organisasi dan Motivasi Kerja Terhadap Prestasi Pegawai Administasi Serta Dampaknya Pada Kinerja Politeknik Negeri Lhoseumawe Aceh. Jurnal Manajemen, 2(1), 199-2302.

Northouse, P. G. (2013). Leadership: Theory and Practice (6th ed.). Thousand Oaks: Sage Publications, Inc.

Noviyanti, E., Syofyan, E., \& Evanita, S. (2019). The Effect of Leadership, Work Motivation and Work Satisfaction on Performance of Employees of Education and Culture Department in Padang Pariaman. Third International Conference On Economics Education, Economics, Business and Management, Accounting and Entrepreneurship (PICEEBA 2019), 685-695. Padang: Atlantis Press.

Para-González, L., Jiménez-Jiménez, D., \& Martínez-Lorente, A. R. (2018). Exploring the mediating effects between transformational leadership and organizational performance. Employee Relations, 40(2), 412-432. https://doi.org/https://doi.org/10.1108/ER-10-20160190

Pasolong, H. (2015). Kepemimpinan Birokrasi (4th ed.). Bandung: Alfabeta.

Rathore, K., Khaliq, C. A., \& Aslam, N. (2017). The Influence of Leadership Styles on Employees Performance under Perceptions of Organizational Politics: A Study of Telecom Sector in Pakistan. International Journal of Management Research and Emerging, 7(1), 106-140.

Rismayadi, B., \& Maemunah, M. (2016). Pengaruh Motivasi Kerja, Kepemimpinan dan Budaya Organisasi Terhadap Kepuasan Kerja Karyawan serta Dampaknya pada Kinerja Perusahaan (Studi kasus pada PT. Concord Indonesia). Jurnal Manajemen \& Bisnis Kreatif, 2(1), 133157.

Ritonga, E. Y. (2018). Pentingnya Penilaian Prestasi Kerja Dalam Organisasi. AL-IDÂRAH Jurnal Pengkajian Dakwan Dan Manajemen, V(6), 13-35.

Robbins, S. P., \& Judge, T. A. (2014). Buku Perilaku Organisasi Buku 2 (Edisi ke-1; alih bahasa D. Angelica, Ed.). Salemba Empat.

Rosmanidar, Hafasnuddin, \& Nurdin, R. (2020). Effect of Work Motivation and Discipline on Employee Performance: Mediating Role of Organizational Commitment. East African Scholars Journal of Economics, Business and Management, 3(3), 238-244. https://doi.org/10.36349/EASJEBM.2020.v03i03.006

Siagian, S. P. (2014). Manajemen Sumber Daya Manusia. Jakarta: Bumi Aksara.

Sinaga, T., \& Sinambela, M. (2013). Pengaruh Stres Kerja Terhadap Motivasi Dan Kinerja Auditor Pada Kantor Akuntan Publik Di Kota Medan. Jurnal Akuntansi, XVII(1), 75-83.

Soetrisno, E. (2016). Manajemen Sumber Daya Manusia (Cetakan Ke). Jakarta: Prenada Media Gorup. 
Suprihatiningrum, H., \& Bodroastuti, T. (2012). Faktor-Faktor Yang Mempengaruhi Prestasi Kerja (Studi Pada Karyawan Kantor Kementrian Agama Provinsi Jawa Tengah). Jurnal Kajian Akuntansi Dan Bisnis, 1(1), 1-23.

Suwaji, R. (2019). Pengaruh Motivasi Kerja, Kepemimpinan Dan Budaya Organisasi Terhadap Kepuasan Kinerja Karyawan Serta Dampaknya Pada Kinerja Perusahaan. MAPAN: Jurnal Manajemen Akuntansi Palapa Nusantara, 4(1), 48-54.

Tarmidi, D., \& Arsjah, R. J. (2019). Employee and Organizational Performance: Impact of Employee Internal and External Factors, Moderated by Online Application. Journal of Resources Development and Management, 57, 30-37. https://doi.org/10.7176/JRDM/57-04

Wani, C. E., Adam, M., \& Majid, M. S. A. (2018). The Mediated Effect of Job Satisfaction on the Relationships between Leadership Effectiveness, Organizational Support, Working Environment and Ability: The Case of State-Owned Electricity Company in Indonesia. IOSR Journal of Business and Management (IOSR-JBM), 20(9), 68-74. https://doi.org/https://doi.org/10.9790/487X-2009066874

Wibowo. (2015). Perilaku Dalam Organisasi (2nd ed.). Medan: Raja Grafindo Persada.

Yamanie, I. Y., \& Syaharuddin. (2016). Pengaruh Penilaian Prestasi Kerja, Komitmen Organisasi Dan Disiplin Kerja Terhadap Kinerja Karyawan Pada PT. Pelabuhan Indonesia IV Cabang Samarinda. Jurnal Manajemen, 8(1), 55-65. 